\title{
THE NEURAMINIC ACID CONTENT OF CEREBROSPINAL FLUID AS AFFECTED BY NEUROLOGICAL DISEASES *
}

\author{
By L. LAHUT UZMAN, EDGAR A. BERING, JR. AND CHARLES E. MORRIS
}

(From the Harvard Neurological Unit, Boston City Hospital; the Department of Neurology, Harvard Medical School; and the Neurosurgical Service Children's Medical Center, Department of Surgery, Harvard Medical School, Boston, Mass.)

(Submitted for publication December 22, 1958; accepted June 12, 1959)

Interest in the presence of neuraminic acid in human cerebrospinal fluid (CSF) and the variations in its concentration is derived from the possibility that these may reflect some aspect of central nervous metabolic activity. This, in turn, is based on the fact that neuraminic acid constitutes a part of the molecular structure of those water soluble glycolipids of brain that are generally referred to as gangliosides (1). However, the ubiquitous nature of neuraminic acid in all tissue fluids and structures renders any inquiry based on analysis of CSF for neuraminic acid alone of doubtful significance. It need only be pointed out that neuraminic acid is found in many tissues either as part of the tissue gangliosides or else in mucoprotein-bound forms in such diverse structures as submaxillary glands $(2,3)$, urinary mucins $(4)$, human serum $(5,6)$, red cell stroma $(1,7,8)$ and even the somatic glycolipid of Escherichia coli (9). Hence, in assessing the significance of changes in the neuraminic acid content of CSF, the major problem resolves itself into excluding the neuraminic acid contributed by the serum to the CSF as well as that moiety derived from cellular elements (white and red cells) extrinsic to the central nervous system.

The discovery by Böhm, Dauber and Baumeister $(5,10)$ that serum contains neuraminic acid (NA) in protein-bound form was followed by the demonstration by Uzman and Rosen (11) that the maximal concentration of NA occurred in the glyco-proteins of the $\alpha_{1}$ - and $\alpha_{2}$-globulin group, with a preponderance in the latter. This was confirmed by the studies of Baudouin, Lewin and Hillion (12), Jayle (13) and others. Since the total NA in serum is almost entirely in nondialyzable form and is almost completely accounted

* Supported by a research grant (B-712) from the National Institute of Neurological Disease and Blindness, United States Public Health Service. for by the fraction precipitated by trichloracetic acid $(14,15)$, the methods initially used for the analysis of NA in CSF were adaptations of those used on serum and thus designed to give values only for the protein-bound forms of NA in the CSF. Consequently, early investigations confined to protein-bound fractions precipitated by ethanol and trichloracetic acid (16) disclosed the presence of only this form in CSF, levels of $2.4 \mu \mathrm{g}$. per $\mathrm{ml}$. CSF being reported. Subsequent studies on protein-bound NA in the CSF (6) indicated "normal" protein-bound NA levels of $1.4 \mu \mathrm{g}$. per ml., although levels reaching as high as $122 \mu \mathrm{g}$. per $\mathrm{ml}$. were also observed in cases of meningitis where the CSF protein levels were proportionately elevated. Further studies by Ross and Böhm (17) on the protein-bound NA suggested a "normal" value of $2.7 \pm 0.55 \mu \mathrm{g}$. per ml. CSF. Although a great variety of neurological diseases was studied by these authors, no pathological process could be correlated with any specific change in protein-bound NA levels. Any process which would be expected to give a rise of the CSF protein concentration also produced a rise in the protein-bound NA concentration.

This picture was modified when studies from this laboratory established that the NA in the CSF is present in two distinct forms (14). The first form is represented by the fraction which is nondialyzable and partly precipitated by trichloracetic acid. This corresponds to the protein-bound forms studied by Böhm, Baumeister and Ross $(6,17)$. The second fraction is the freely dialyzable NA moiety of CSF. This fraction was shown to account for 60 to 80 per cent of the total NA content of normal human CSF. Since a similar fraction does not appear to occur in demonstrable amounts in serum it was suggested that this freely dialyzable NA fraction may be derived from the metabolic activity of the central nervous 
system. The present study constitutes an inquiry into the significance of variations of NA concentration of the CSF in different neurological diseases, especially with respect to the freely dialyzable NA fraction. Also, by a study of the differences of NA concentration (dialyzable and protein-bound) in ventricular and spinal fluid in cases of known types of pathology, the site of production of the dialyzable NA fraction and the pathological conditions that provide the factors necessary to induce changes in the concentration of this fraction are defined.

\section{MATERIALS AND METHODS}

CSF samples were obtained in the course of routine diagnostic lumbar puncture, pneumoencephalography or myelography. Ventricular fluid samples were obtained either in the course of diagnostic ventriculography or by direct puncture through the frontal fontanelle in cases of hydrocephaly or Arnold-Chiari syndrome. In a few instances ventricular fluid was collected from an inlying catheter in patients in whom ventricular drainage was performed. Such samples will be designated hereafter as "drainage samples." For the study of the variation of NA in different parts of the subarachnoid space, a lumbar puncture was performed with the patient in sitting position. As soon as it was ascertained that the puncture was nontraumatic, spinal fluid was allowed to flow out under its own pressure directly into clean collection tubes. Three or four samples, each exactly of $5.0 \mathrm{ml}$. volume, were sequentially collected. One $\mathrm{ml}$. of each sample was used for total protein estimation by the method employed previously (14) while $3.0 \mathrm{ml}$. was taken for NA analysis. In those cases where ventricular and spinal puncture were performed simultaneously the ventricular fluid was withdrawn immediately before fluid was allowed to run out of the needle in the lumbar subarachnoid space so that the initial composition of the ventricular fluid was not disturbed.

Neuraminic acid estimation. The analytical procedures were essentially those previously employed (14). The analysis was performed usually on $3.0 \mathrm{ml}$. of CSF directly, using the procedure of Böhm and colleagues $(5,6)$ with Bial's reagent. Where NA in protein precipitates was analyzed, the precipitated samples were made up to $1.0 \mathrm{ml}$. with water and the whole procedure modified accordingly. In some instances the direct reaction with Ehrlich's reagent, as described by Werner and Odin (18), was used to check the quantitative partition of NA in the protein-bound and freely dialyzable fractions. Since, however, the direct reaction with Ehrlich's reagent lacks the desired specificity in spite of extreme sensitivity, the method was used only to corroborate the NA content obtained with Bial's reagent. The main source of error in direct Ehrlich reaction is the color given by $\alpha$-pyrrole carboxylic acid (19). Total NA val- ues were obtained by treating a $3.0 \mathrm{ml}$. sample of $\mathrm{CSF}$ with $3.0 \mathrm{ml}$. Bial's reagent (5) in a boiling water bath for 15 minutes. The tubes were cooled and the resulting color extracted into $3.0 \mathrm{ml}$. of $n$-amyl alcohol, by shaking and centrifugation. The amyl alcohol layer was removed with a capillary pipette, and the absorption of the gray-lavender color compared at $570 \mathrm{~m} \mu$ against a similarly treated $3.0 \mathrm{ml}$. water blank. The amount of NA was calculated from the extinction of a standard curve obtained with pure methoxy-neuraminic acid isolated from serum. Duplicates agreed within 1 per cent. The value for total NA thus obtained was corrected for glucose content of the sample whenever necessary as described in the next section.

Since the identity of serum and CSF neuraminic acid has not yet been unequivocally established as being solely represented by the $n$-acetyl derivative, and because the majority of values in the literature are reported essentially as methoxy-neuraminic acid equivalents, the results of our study are also presented in this manner. Thus all NA values reported here are "methoxyneuraminic acid equivalents."

The methoxy-NA preparation used for the standard curve was a crystalline product isolated from serum (10). It migrated as a single substance in the chromatographic systems described by Klenk, Faillard and Lempfrid (4). The molar ratio of $\alpha$-amino nitrogen to carboxyl groups (titration) was 1.01. Analysis gave:

Found $\quad \mathrm{C}=42.44 \quad \mathrm{H}=6.80 \quad \mathrm{~N}=4.50$

Expected for $\mathrm{C}_{11} \mathrm{H}_{21} \mathrm{O}_{9} \mathrm{~N} \quad \mathrm{C}=42.67 \quad \mathrm{H}=6.96 \quad \mathrm{~N}=4.48$

Comparison of the color value of methoxy-NA with Bial's reagent and that of crystalline $n$-acetyl-NA ${ }^{1}$ obtained from brain strandin (a ganglioside) showed that the $n$-acetyl derivative gave only 73.9 per cent of the color obtained with an equal amount (by weight) of methoxyNA over a wide range of concentrations tested. Using this conversion factor $(100 / 73.9)$, the values presented in this study can be converted easily to $n$-acetyl-NA equivalents should future studies prove that all of the protein-bound and dialyzable NA fractions of CSF are identical with $n$-acetyl neuraminic acid.

Protein-bound NA precipitated with trichloracetic acid (TCA-pptd. NA) was determined by treating $3.0 \mathrm{ml}$. of $\mathrm{CSF}$ with $3.0 \mathrm{ml}$. of cold 10 per cent trichloracetic acid. The precipitate was allowed to collect in the refrigerator for 30 minutes. The supernatant was discarded after centrifugation. The precipitate was next suspended in $1.0 \mathrm{ml}$. water and treated with $1.0 \mathrm{ml}$. Bial's reagent in

${ }^{1}$ Kindly provided by Dr. J. Folch-Pi. The analytical authentication of this preparation by Dr. J. Folch-Pi was confirmed by analysis and X-ray diffraction patterns by Professor Blix and established as being identical with $n$-acetyl-neuraminic acid of ovine submaxillary mucin. Detailed information on this preparation has recently been published (Folch-Pi, J., and Lees, M. Studies on the brain ganglioside strandin in normal brain and in Tay-Sach's disease. J. Dis. Child. 1959, 97, 730). 


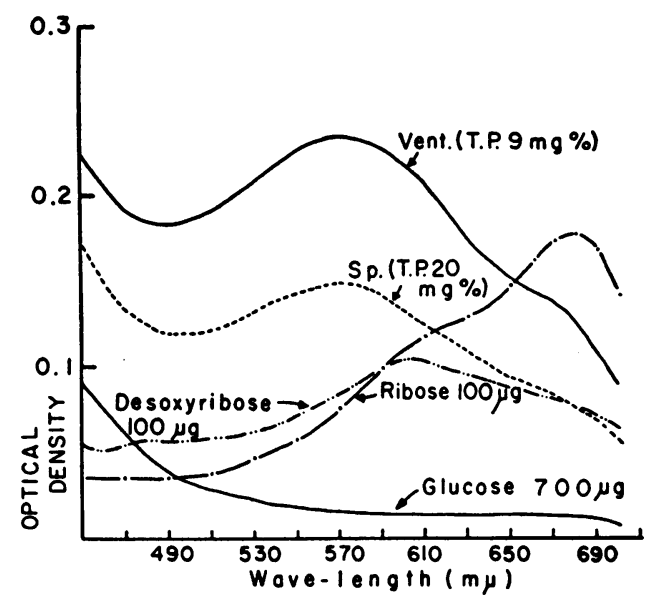

Fig. 1. Absorption Spectra of Colored Reaction Products of CSF, Glucose, Ribose and Desoxyribose with Bial's Reagent

Note that absorption at $570 \mathrm{~m} \mu$ of $\mathrm{NA}$ in ventricular fluid is much higher than that of spinal fluid even though the former has a much lower protein content $(9 \mathrm{mg}$. per cent). The nonspecific absorption of desoxyribose and ribose at $570 \mathrm{~m} \mu$ invalidates NA determinations in CSF containing large numbers of white cells.

a boiling water bath for 15 minutes. A blank containing only water $(1.0 \mathrm{ml}$.) and Bial's reagent was similarly treated. The color was extracted into $3.0 \mathrm{ml}$. $n$-amyl alcohol and the NA content determined from the extinction at $570 \mathrm{~m} \mu$. Duplicates agreed within 3.0 per cent.

Protein-bound nondialyzable NA (nondialyzable NA) was estimated by dialyzing $3.0 \mathrm{ml}$. of CSF for 18 hours against water in a viscose dialysis bag. The contents were quantitatively recovered (with distilled water washings) and made up to $5.0 \mathrm{ml}$. volume; $3.0 \mathrm{ml}$. aliquots were used for the estimation of total NA as described above. The calculated nondialyzable NA values agreed within 5 per cent in duplicate determination.

Specificity of the method and correction for glucose content. In order to eliminate the possibility that substances other than NA and its chromogenic derivatives were also being measured with Bial's reagent, the following substances were tested both as aqueous solutions individually and after adding to samples of CSF appropriate amounts of glucose, galactose, D-glucosamine, $n$-acetylD-glucosamine, D-arabinose, D-galacturonic acid, $\alpha$-methylD-glucoside tetra-acetate, $i$-erythritol, tetra-acetyl-D-glucose, D-ribose, 2-desoxy-D-ribose, lactose, pyruvic acid and oxaloacetic acid. The hexoses and their derivatives yielded a pale yellow-orange product which, extracted into $n$-amyl alcohol, showed no specific absorption peak at $570 \mathrm{~m} \mu$ but had greater absorption below $440 \mathrm{~m} \mu$ (Figure 1). The pentoses on the other hand showed (in $100 \mu$ g. per $\mathrm{ml}$. concentration) a very significant absorption at $570 \mathrm{~m} \mu$ even though the absorption peak of the blue color itself was at $690 \mathrm{~m} \mu$ for ribose and 600 $\mathrm{m} \mu$ for desoxyribose (Figure 1). Since sedoheptulose is known to be the only other subtance which produces a specific absorption peak at $570 \mathrm{~m} \mu$ with Bial's reagent (20), this was also tested for in a number of samples by the independent cysteine-sulfuric acid reaction (20) and its absence was established. Pyruvic and oxaloacetic acids produced no color.

Although glucose has no specific absorption at $570 \mathrm{~m} \mu$, the normally high concentration of glucose in the CSF made it necessary to correct for the nonspecific absorption of the yellow-gray color produced with Bial's reagent in the determination of total NA. The interference was negligible in the estimations of nondialyzable or TCAprecipitated NA. The interference was especially marked when the glucose concentration in the CSF was above 40 $\mathrm{mg}$. per $100 \mathrm{ml}$. This interference can be detected in any given sample by measuring the optical density of the test solution both at $490 \mathrm{~m} \mu$ and at $570 \mathrm{~m} \mu$. Whenever the ratio $E_{400 \mathrm{~m} \mu} / E_{570 \mathrm{~m} \mu}$ exceeded 0.76 the total $\mathrm{NA}$ value had to be corrected for glucose. This was done by an independent analysis of CSF glucose content. This value was read off a glucose curve obtained with Bial's reagent under the same conditions used in the NA analysis to give the Bial color equivalent of the glucose in that particular sample. The contribution of the glucose content to the NA value was subtracted from the total Bial color density to give the true total NA content of the sample (Figure 2).

After completion of this study we were informed by Dr. Eli Robins (21) that ascorbic acid gives sufficient color with Bial's reagent to cause some possible inter-

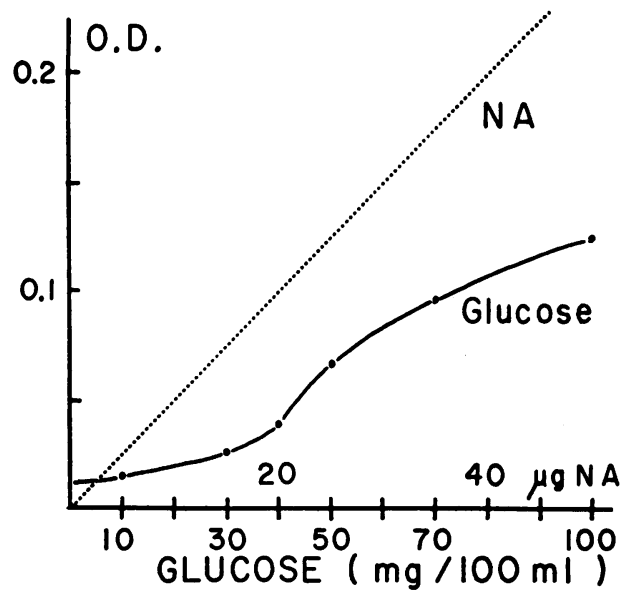

Fig. 2. Correction for Glucose Content in DeterMINATION OF TOTAL NA

The glucose concentration (mg. per $100 \mathrm{ml}$. CSF) of the sample, read on the abscissa, is related to the corresponding glucose Bial color in a $3.0 \mathrm{ml}$. CSF sample, by reading off the Bial glucose curve (solid line). This is converted to NA equivalents by reading the corresponding value off the NA curve (dotted line). The figure thus obtained gives the amount of "false" NA which has to be subtracted from the total NA to give the actual total NA content in $3.0 \mathrm{ml}$. of CSF. 
ference in the estimation of total NA in the CSF. We have explored this possibility using a wide range of ascorbic acid concentrations. It was found that up to concentrations of $0.4 \mathrm{mg}$. per $\mathrm{ml}$. the reaction product with Bial's reagent was pink (maximum absorption at $550 \mathrm{~m} \mu$ ). This changed to brown-green (maximum at $590 \mathrm{m \mu}$ ) at $1.2 \mathrm{mg}$. per ml. ascorbic acid concentration. The lowest concentration of ascorbic acid which produced an interference $(0.15 \mathrm{mg}$. per $\mathrm{ml}$.) was found to represent about 10 times the natural concentration of ascorbic acid in CSF. It seems therefore unlikely that this could prove a source of error.

\section{RESULTS}

Total NA in CSF samples. A survey of some further 250 samples of CSF conforming to the criteria delineated above (no pleocytosis, no red cells) but containing a wide spectrum of total protein, confirmed our previous report (14) that the total NA content of CSF is largely dependent on the total protein content, especially at elevated protein levels (Figure 3). However, at normal total protein levels (below $30 \mathrm{mg}$. per $100 \mathrm{ml}$. CSF) the spread in total NA was quite wide. At this level of total protein the contribution of the dialyzable NA to the total NA level was considerable ( 40 to 60 per cent) and hence these variations were more easily reflected in the form in which they are expressed (NA as per cent total protein) on logarithmic coordinates for correction of the factor of protein-bound NA. Before any interpretation of the level of dialyzable NA in CSF could be made, it was essential to ascertain whether the dialyzable fraction varied in concentration in the same individual according to the site from which fluid was removed. In other words, although CSF total protein content shows an exponential gradient of increasing concentration from the ventricular reservoir to the lumbar subarachnoid sac, one had to determine whether the total NA concentration maintained the same relationship to the protein at different levels in the subarachnoid space.

Changing concentration of $N A$ in ventricular and spinal subarachnoid spaces. The problem of establishing whether the NA content showed an orderly change in concentration, depending on its concentration at different levels from the lateral ventricles to the lumbar subarachnoid space, was first approached by sequential sampling of CSF $(5 \mathrm{ml}$. aliquots) from the same individual under

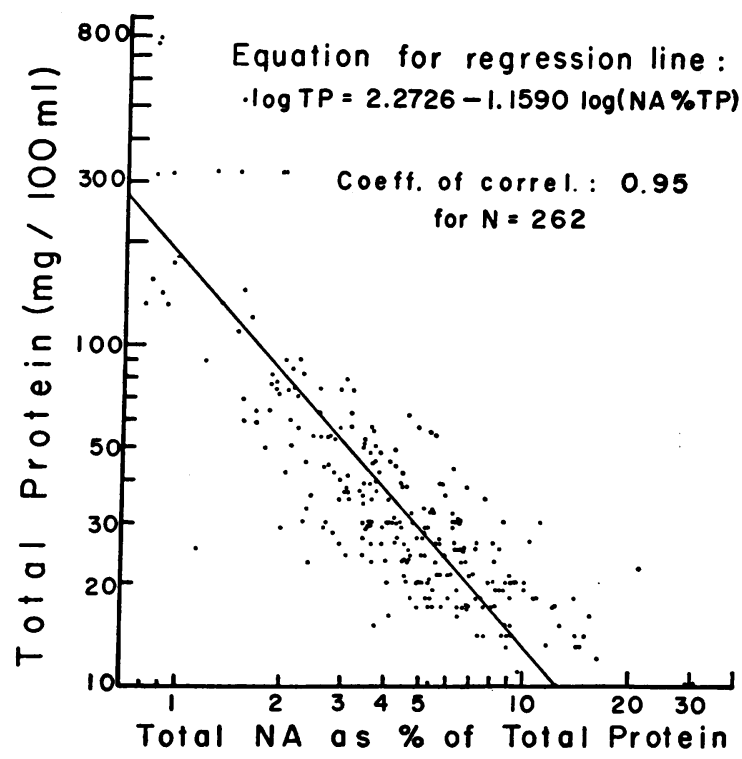

Fig. 3. Relationship of CSF Total NA Levels to Total Protein

conditions in which any disturbance of concentration gradients by manipulations on the examiner's or the patient's part were avoided. Any changes induced by the examiner, such as exerting negative pressure on the syringe (aspirating) or collecting different volumes in three or more tubes in sequence were avoided. Similarly, samples collected while the patient moved, coughed, sneezed, struggled or yawned during the procedure invalidated the inquiry, as will be shown. Samples thus collected and analyzed for total protein and total NA revealed as expected that the dialyzable NA concentrations rose exponentially so that the values of the total NA expressed as per cent of total protein and plotted on logarithmic coordinates fell exactly on a straight line (Figure 4). That this phenomenon depended on the maintenance of the natural exponentially-increasing concentration gradient for CSF protein (and protein-bound NA) and the exponentially-decreasing concentration gradient for dialyzable NA was clearly demonstrated when $5.0 \mathrm{ml}$. samples were removed sequentially from subjects, but $5.0 \mathrm{ml}$. of air was injected before the next $5.0 \mathrm{ml}$. sample was collected (Figure 5). In these cases, although the same straight line trend was obvious, the points no longer fell exactly on a straight line. The dependence of unbound NA concentration on the 


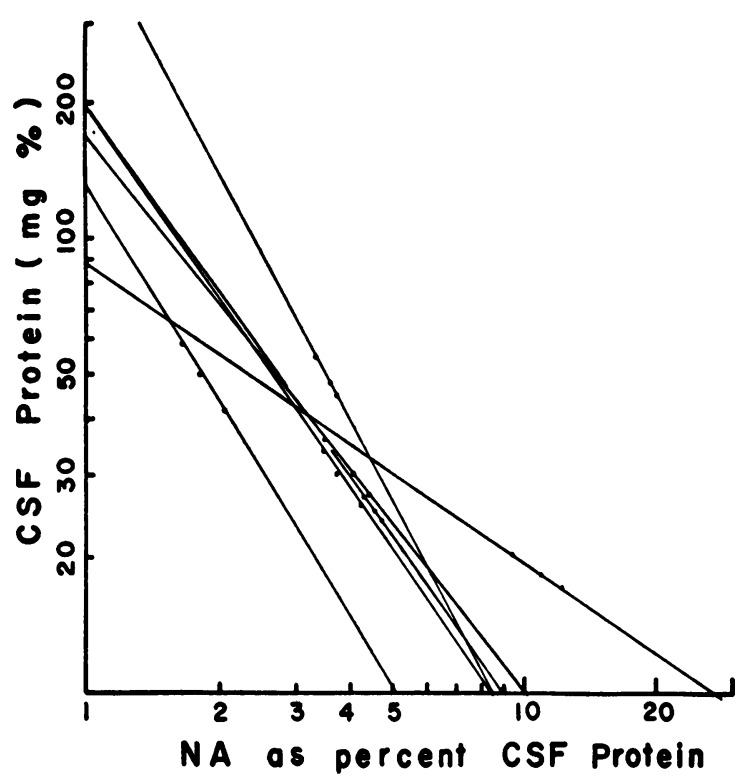

Fig. 4. Exponential Decrease of Total Protein and Exponential Increase of Dialyzable NA MoIety of CSF in Sequentially Removed Equal Volumes (5.0 ML.) of CSF

In each case the first sample has the highest protein concentration. When the normal concentration gradients are not disturbed the values fall on an exact straight line when exponential coordinates are used.

volume of CSF removed from the lumbar subarachnoid space was also evident when the samples removed in sequence from different patients were of unequal volume. As seen in Table I, the total NA content of successive aliquots removed from the lumbar subarachnoid space still constituted a successively larger percentage of the total protein which itself decreased as CSF, originally higher up in the subarachnoid space, reached the withdrawal site. Yet a straight line relationship was no longer evident because of the unequal volumes of the samples.

Simultaneous ventricular-spinal punctures. To confirm the changes in NA concentration observed on sequential removal of equal aliquots of CSF in a direct manner, simultaneous ventricular and spinal taps were performed with the patient lying on his side in six instances. These observations are recorded in Table II. Wide differences in the NA content of ventricular and spinal fluids were in evidence whenever there was some block at the outlet of the ventricular system (Table II, Cases 1 and 2). Although the protein-bound NA was higher in the spinal fluid than in the ventricular cavity, the dialyzable NA moiety was much higher within the ventricular than within the spinal subarachnoid space, as evidenced by a much higher total NA per cent total protein value. This was also true in one case (No. 6) where such a block to the CSF circulation could not be demonstrated. On the other hand, the cases showing a resorptive defect (Nos. 3 and 4 ) and decreased ventricular NA production (No. 5) showed an equalization of the $\mathrm{NA} /$ total protein ratio in the ventricular and spinal fluids.

Variations in NA concentration in the ventricle in pathological states. In view of the foregoing results it would be expected that in internal hydrocephalus, with block either at the level of the aqueduct or the fourth ventricle (noncommunicating hydrocephalus), the content of dialyzable NA would be very high. That such is indeed the case was shown by study of the composition of ventricular fluid from a number of infants in whom total obstruction of the fourth ventricle could be demonstrated. The samples were obtained either by ventricular tap or by continuous drainage (Table III). In six cases of noncommunicating hydrocephalus the average NA content was 27.1 $\mu \mathrm{g}$. per ml. fluid even though in five of these cases

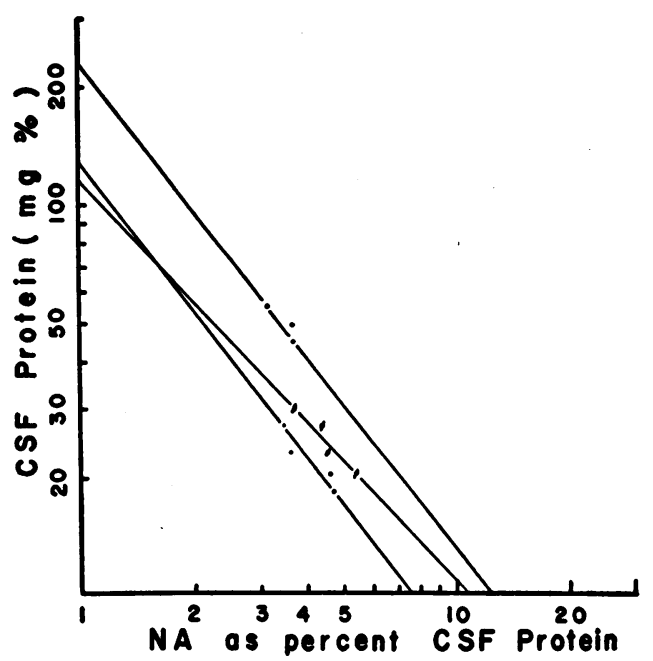

Fig. 5. Effect of Deliberate Disturbance of ConCENTRATION GRADIENTS

Sequentially removed equal volume samples of CSF where the concentration gradients for total protein and NA have been deliberately disturbed by the injection of $5.0 \mathrm{ml}$. of air between each sample withdrawal. 
the total protein content was low. Consequently the contribution of the TCA-precipitated NA to the total was very low too. The exception to this was the observation on the hydrocephalic twins (S.P. and L.P.) in whom a high total NA content was accompanied by a high protein level. These infants had noncommunicating hydrocephalus secondary to severe malformations of the proencephalon and mesencephalon. The atresia of the aqueductus Sylvii was confirmed at autopsy some time later, as communicated to one of us by Dr. Philip Dodge. The observations on cases of noncommunicating hydrocephalus contrasted strikingly with the findings in those cases in which it could be definitely established that the internal hydrocephalus was a communicating one, either by air studies or by the passage of phenolsulfonphthalein from the ventricular to the spinal subarachnoid space. The ventricular total NA content was significantly lower in these patients (average, 17.9 $\mu \mathrm{g}$. per $\mathrm{ml}$.) even though in all these cases the ventricular protein (and consequently the TCApptd. NA) was very much higher (Table III).

Adult patients who had severe cerebral disease of different types and from whom suitable ventricular fluid samples could be obtained showed a remarkably different picture (Table IV). We have included only those cases in which the diagnosis was unequivocally confirmed at operation or autopsy. These cases fell into two groups. Group A was characterized clinically by evidence of progressive increase in intracranial pressure and cerebral edema, with stupor or coma of at least 48 hours' duration. In none of these patients was there any clear cut lateralization of neurological signs. Group B represented patients over the age of 40 with focal seizures of recent onset, or with dementia and focal signs suggesting the possibility of tumor. These patients, with one exception, were alert though often disoriented. In only one patient (F.D.) in this group was there rapidly developing stupor after an acute head injury, but he was included because at the time of ventriculography evidence for increased intracranial pressure and stupor was of only a few hours' duration.

As is evident from Table IV the total NA content was uniformly very low in Group A (average total NA, $9.5 \mu \mathrm{g}$. per ml. CSF). Even in those cases where the protein content was markedly
TABLE I

Sequential samples of unequal volume removed from lumbar subarachnoid space

\begin{tabular}{|c|c|c|c|c|}
\hline Case & $\begin{array}{c}\text { Sample } \\
\text { no. }\end{array}$ & $T P^{*}$ & $\begin{array}{c}\text { Total } \\
\text { NAt }\end{array}$ & NA/TP \\
\hline & & $\underset{\mathrm{ml} .}{\mathrm{mg} . / 100}$ & $\mu g . / m l$. & per cent \\
\hline $\begin{array}{l}\text { M. W. } \\
\text { Epilepsy }\end{array}$ & II & $\begin{array}{l}20 \\
18 \\
17\end{array}$ & $\begin{array}{l}18.7 \\
19.7 \\
20.5\end{array}$ & $\begin{array}{r}9.35 \\
10.90 \\
12.02\end{array}$ \\
\hline $\begin{array}{l}\text { M. I. } \\
\text { Temp. lobe seizures, } \\
\text { postictal, } 12 \text { hours }\end{array}$ & $\begin{array}{l}\text { II } \\
\text { III } \\
\text { IV }\end{array}$ & $\begin{array}{l}27 \\
23 \\
20 \\
18\end{array}$ & $\begin{array}{l}9.4 \\
8.4 \\
9.2 \\
8.5\end{array}$ & $\begin{array}{l}3.48 \\
3.65 \\
4.60 \\
4.72\end{array}$ \\
\hline $\begin{array}{l}\text { B. Sy. } \\
\text { Spastic diplegia, } \\
\text { congenital }\end{array}$ & II & $\begin{array}{l}17 \\
17 \\
14\end{array}$ & $\begin{array}{l}11.7 \\
11.0 \\
12.2\end{array}$ & $\begin{array}{l}6.89 \\
6.48 \\
8.70\end{array}$ \\
\hline $\begin{array}{l}\text { H. R. } \\
\text { Hypertensive } \\
\text { encephalopathy }\end{array}$ & II & $\begin{array}{l}60 \\
44 \\
40\end{array}$ & $\begin{array}{r}9.3 \\
12.0 \\
11.7\end{array}$ & $\begin{array}{l}1.55 \\
2.73 \\
2.93\end{array}$ \\
\hline One month later & II & $\begin{array}{l}34 \\
30 \\
26\end{array}$ & $\begin{array}{l}11.7 \\
11.1 \\
11.1\end{array}$ & $\begin{array}{l}3.44 \\
3.70 \\
4.27\end{array}$ \\
\hline $\begin{array}{l}\text { D. B. } \\
\text { Basilar artery insuff. }\end{array}$ & II & $\begin{array}{l}36 \\
30 \\
27\end{array}$ & $\begin{array}{l}12.5 \\
12.1 \\
11.5\end{array}$ & $\begin{array}{l}3.47 \\
4.03 \\
4.36\end{array}$ \\
\hline $\begin{array}{l}\text { F. C. } \\
\text { Basilar artery insuff. }\end{array}$ & $\begin{array}{l}\text { I } \\
\text { II } \\
\text { II } \\
\text { IV }\end{array}$ & $\begin{array}{l}32 \\
30 \\
26 \\
23\end{array}$ & $\begin{array}{l}19.9 \\
18.7 \\
19.0 \\
18.9\end{array}$ & $\begin{array}{l}6.22 \\
6.23 \\
7.31 \\
8.22\end{array}$ \\
\hline $\begin{array}{l}\text { J. O'S. } \\
\text { Middle cerebral insuff. }\end{array}$ & $\begin{array}{c}\text { I } \\
\text { III } \\
\text { IV }\end{array}$ & $\begin{array}{l}27 \\
25 \\
24 \\
24\end{array}$ & $\begin{array}{l}11.6 \\
11.3 \\
11.3 \\
12.3\end{array}$ & $\begin{array}{l}4.30 \\
4.52 \\
4.71 \\
5.12\end{array}$ \\
\hline $\begin{array}{l}\text { E. T. } \\
\text { Carotid insuff. }\end{array}$ & $\underset{\text { III I }}{\text { I }}$ & $\begin{array}{l}55 \\
48 \\
45\end{array}$ & $\begin{array}{l}18.4 \\
17.3 \\
16.6\end{array}$ & $\begin{array}{l}3.35 \\
3.60 \\
3.69\end{array}$ \\
\hline
\end{tabular}

* Total protein.

$\dagger$ Neuraminic acid.

elevated, the protein-bound NA represented a relatively small portion of the total NA concentration, indicating an absolute decrease in the dialyzable NA level as well as in the protein-bound moiety. On the other hand, Group B showed only slightly elevated protein levels, while the average total NA content (17.4 $\mu$ g. per ml.) was almost double that observed in the ventricular fluid of patients in Group A. The difference between the two groups was further accentuated by the finding that in spite of higher total levels the ventricular fluid in Group B had a much lower protein-bound NA content. In other words, the dialyzable NA was very much higher in Group B than in Group A. 
TABLE II

Results of combined ventricular and spinal taps

\begin{tabular}{|c|c|c|c|c|c|c|c|c|c|c|}
\hline \multirow[b]{2}{*}{ Case } & \multirow[b]{2}{*}{ Age } & \multicolumn{3}{|c|}{ Right ventricle } & \multicolumn{3}{|c|}{ Left ventricle } & \multicolumn{3}{|c|}{ Spinal fluid } \\
\hline & & TP* & $\begin{array}{l}\text { Total } \\
\text { NA† }\end{array}$ & NA/TP & TP & $\begin{array}{l}\text { Total } \\
\text { NA }\end{array}$ & NA/TP & TP & $\begin{array}{l}\text { Total } \\
\text { NA }\end{array}$ & NA/TP \\
\hline \multirow{7}{*}{$\begin{array}{l}\text { 1. H. D. Hydrocephalus } \\
\text { (aqueductal atresia) } \\
\text { 2. R. S. Basal arachnoiditis } \\
\text { (4th ventricle block) } \\
\text { 3. B. McL. Communicating } \\
\text { hydrocephalus } \\
\text { 4. B. B. Communicating } \\
\text { hydrocephalus } \\
\text { 5. K. B. Right thalamic } \\
\text { hemorrhage } \\
\text { 6. W. O. Wernicke's } \\
\text { encephalopathy }\end{array}$} & yrs. & $\begin{array}{c}m g . l \\
100 \mathrm{ml} .\end{array}$ & $\mu g . / m l$. & per cent & $\begin{array}{c}m g . l \\
100 \mathrm{ml} \text {. }\end{array}$ & $\mu g . / \mathrm{ml}$. & per cent & $\underset{100 \mathrm{ml} .}{m .}$ & $\mu g . / m l$. & per cent \\
\hline & $5 / 12$ & 7 & 7.2 & 10.30 & 6.0 & 6.7 & 11.20 & 17 & 8.46 & 4.98 \\
\hline & $5 / 12$ & 25 & 18.21 & 7.36 & 19.0 & 19.0 & 10.00 & 50 & 18.6 & 3.72 \\
\hline & $3 / 12$ & 21 & 14.4 & 7.00 & 20.0 & 16.6 & 7.85 & 39 & 13.5 & 3.49 \\
\hline & $4 / 12$ & 75 & 17.4 & 2.33 & 73.0 & 23.3 & 3.19 & 79 & 24.2 & 3.05 \\
\hline & 59 & 69 & 10.6 & 1.55 & 64.0 & 10.8 & 1.69 & 90 & 18.2 & 2.02 \\
\hline & 46 & 10 & 10.9 & 10.90 & & & & 17 & 13.1 & 7.70 \\
\hline
\end{tabular}

* Total protein.

† Neuraminic acid.

Changes in NA content of spinal subarachnoid fluid. In 108 cases arbitrarily chosen on the basis of a CSF total protein content of $30 \mathrm{mg}$. per 100 $\mathrm{ml}$. or less, there were 47 samples from patients in whom no neurological disease could be demonstrated. The remaining 61 included samples from patients with chronic degenerative disease (four cases Wilson's disease, three cases Huntington's chorea, four cases presenile dementia, four cases Parkinsonism, two cases Jakob-Creutzfeldt disease, two cases familial spastic paraplegia and two cases primary cerebellar degeneration) and

TABLE III

Neuraminic acid content of ventricular fluid in hydrocephalus

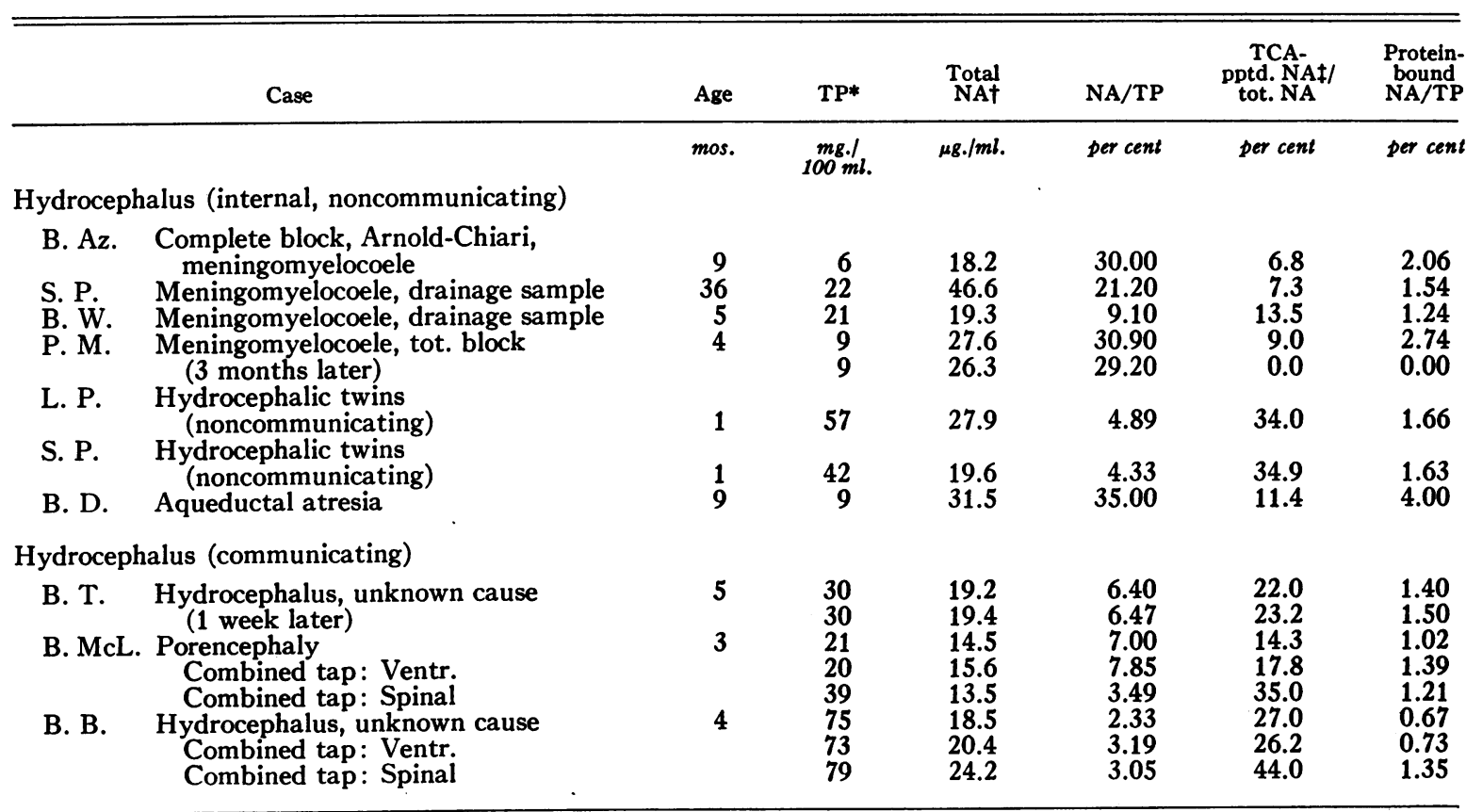

* Total protein.

$\dagger$ Neuraminic acid.

† Trichloracetic acid-precipitated neuraminic acid. 
TABLE IV

Neuraminic acid content of ventricular fluid in adult tumor suspects

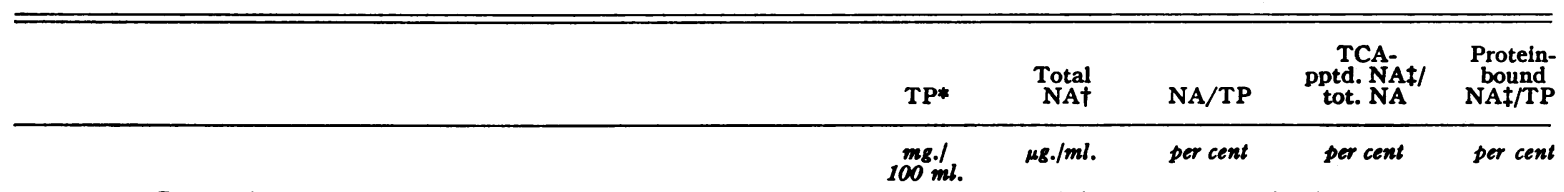

Group A-Patients in coma or stupor, evidence of increased intracranial pressure, cerebral edema

K. B. Right thalamic hemorrhage (no blood in ventricle)

R. L. Right frontal metastatic tumor

A. G. Medulloblastoma with 4th ventricle block

W. L. Subdural hygroma

F. D. Dementia, diabetes

G. M. Metastatic adenocarcinoma

W. T. Subdural abscess

(1 week after operation) Left

$\begin{array}{lrrrrr}\text { Right } & 69 & 10.6 & 1.55 & 38.5 & 0.59 \\ \text { Left } & 64 & 10.8 & 1.69 & 39.8 & 0.67 \\ \text { Right } & 29 & 5.7 & 2.00 & 30.0 & 0.59 \\ \text { Left } & 24 & 7.4 & 3.09 & & \\ & 81 & 16.0 & 1.86 & 34.3 & 0.68 \\ & 29 & 7.8 & 2.66 & 20.5 & 0.55 \\ \text { Right } & 156 & 13.2 & 0.84 & & \\ \text { Left } & 142 & 12.4 & 0.89 & & \\ \text { Left } & 132 & 10.4 & 0.80 & & \\ \text { Left } & 132 & 12.1 & 0.92 & & \\ & 15 & 5.4 & 3.74 & 23.2 & 0.83 \\ & 16 & 6.4 & 4.12 & & \\ & 10 & 5.2 & 5.40 & 18.5 & 0.96\end{array}$

Group B-Patients with dementia and severe focal signs, but alert, no evidence of increased intracranial pressure

G. P. Severe atrophy of right hemisphere

H. McK. Anterior cerebral artery thrombopiseated)

V. F. Cerebral atrophy, old infarct

T. B. Aneurysm, right middle cerebral artery

W. C. Wernicke's encephalopathy

J. D. Alcoholic dementia, focal seizures

J. B. Dementia, large ventricles, metastatic carcinoma

F. K. Acute head trauma, developing stupor and focal signs on right side, aphasia

$\begin{array}{llrrrr}\text { Right } & 17 & 11.6 & 6.94 & 19.1 & 1.30 \\ \text { Left } & 17 & 14.2 & 8.29 & 16.1 & 1.34 \\ \text { Left } & 29 & 10.2 & 3.53 & 28.4 & 1.00 \\ \text { Right } & 12 & 19.2 & 16.25 & 12.6 & 2.02 \\ \text { Right } & 25 & 17.2 & 6.80 & 14.2 & 0.98 \\ \text { Left } & 23 & 15.7 & 6.80 & 14.6 & 0.99 \\ \text { Right } & 15 & 17.4 & 11.60 & 16.7 & 1.93 \\ \text { Left } & 19 & 17.1 & 10.90 & 18.1 & 1.62 \\ \text { Right } & 10 & 10.9 & 10.90 & 9.17 & 1.01 \\ & 24 & 23.4 & 9.75 & 13.67 & 1.34 \\ \text { Right } & 24 & 24.0 & 10.00 & 16.35 & 1.63 \\ \text { Left } & 24 & 24.4 & 10.20 & 15.02 & 1.54 \\ \text { Right } & 15 & 18.6 & 12.40 & 10.27 & 1.27 \\ \text { Left } & 12 & 20.1 & 16.75 & 8.95 & 1.50 \\ & & & & & \end{array}$

* Total protein.

$\dagger$ Neuraminic acid.

† Precipitated by trichloracetic acid.

patients with temporal lobe seizures, chronic cerebral vascular disease and evidence of obstruction of the spinal subarachnoid canal (evidence of block at myelography or at operation). As is evident from the histogram in Figure 6, there was a considerable overlap in the distribution patterns of total NA concentration in the patients with and without neurological disease. The range in the "normal" samples was especially wide ( 8 to $32 \mu \mathrm{g}$. per ml. CSF) with a peak between 16 and $20 \mu \mathrm{g}$. per $\mathrm{ml}$. Those cases with CSF protein levels below $30 \mathrm{mg}$. per $100 \mathrm{ml}$. with evidence of neurological disease had a total NA concentration distribution of 4 to $20 \mu \mathrm{g}$. per $\mathrm{ml}$. CSF with a sharp peak between 8 and $14 \mu \mathrm{g}$. per $\mathrm{ml}$. When this information was further broken down it was seen that all cases with verified spinal subarachnoid obstruction had total NA values below $10 \mu \mathrm{g}$. per ml. CSF. The cases with chronic degenerative

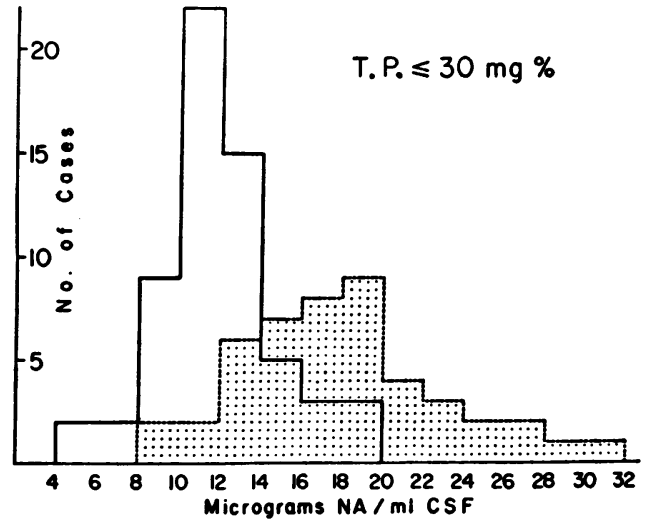

Fig. 6. Overlap of Total NA in Patients With and Without Neurologic Disease

Histogram showing the distribution pattern of total NA concentration in 108 cases arbitrarily chosen because the total protein was $30 \mathrm{mg}$. per cent or less. Stippled area represents normal cases, blank area those with neurological diseases. 


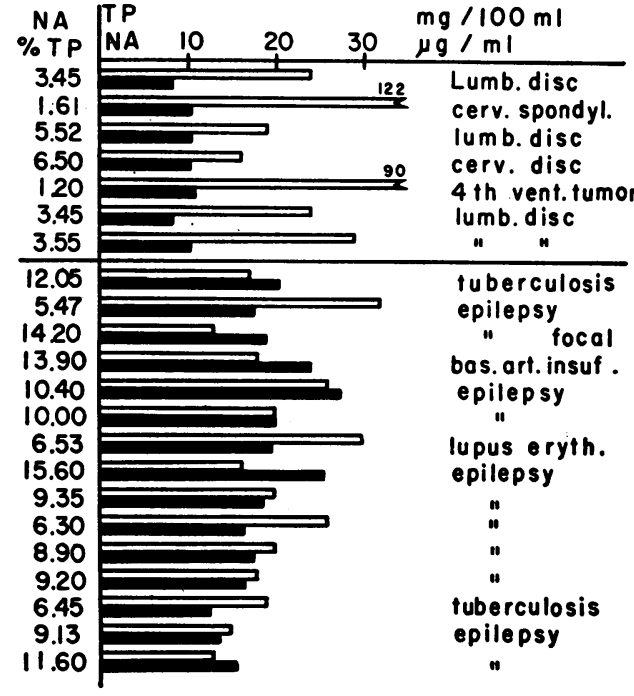

Fig. 7. Reduction of NA in Spinal Block

Showing the markedly reduced NA concentration (less than $10 \mu \mathrm{g}$. per ml.) in lumbar fluid in cases with proven block above the site of sampling, as compared with patients having other types of neurological disorders. Black bars represent total NA concentration, white bars total protein concentration.

disease and chronic cerebral vascular disease represented those values that directly overlapped the "normal" range, the same being true for those patients with convulsive seizures with or without evidence of focal lesions. The striking reduction in the total NA concentration of the CSF in cases with varying degrees of spinal block is illustrated in Figure 7. The seven cases of verified spinal block had NA content below $10 \mu \mathrm{g}$. per ml. irrespective of the protein content, with the total NA representing 1.20 to 6.50 per cent of the total protein (average 3.61 per cent). In contrast, the 15 cases with protein levels in the normal range had total NA concentrations uniformly above 10 $\mu \mathrm{g}$. per $\mathrm{ml}$. with the total NA representing 5.47 to 15.60 per cent of the total protein (average 9.93 per cent).

In all our experience, only one case without evidence of spinal block showed a very low NA content. This was a patient not included in the tables, with severe dementia and bilateral hemiparesis with spasticity, who was shown both by arteriography and surgical exploration to have a total occlusion of both internal carotid arteries. In this patient the CSF total protein was $21 \mathrm{mg}$. per $100 \mathrm{ml}$, the total NA, $9.7 \mu \mathrm{g}$. per ml.; NA as per cent of total protein had a value of 4.55 , but the TCA-pptd. NA represented 17.1 per cent of the total.

The protein-bound $N A$ fraction. Inasmuch as the relatively small volumes of the CSF samples available restricted the analysis of the proteinbound NA moiety to that obtained from analysis of the TCA-pptd. fraction, it was discovered that the latter did not represent the whole of the protein-bound NA moiety. In 48 cases where adequate volumes of CSF were available and different levels of total protein concentration prevailed, analyses of both TCA-pptd. NA and the nondialyzable NA were performed. In all instances the nondialyzable NA fraction was much greater than the TCA-pptd. NA fraction, the latter usually representing only about 50 per cent of the former (Figure 8). The slope for the regression line for the values plotted in Figure 8 was 0.63 , with a standard error about the regression line of 6.73 , and a coefficient of correlation " $r$ " equal to 0.86 . On the other hand, the nondialyzable NA fraction was directly related to the total protein concentration of the CSF in 48 cases studied (Figure 9). In 46 samples with differing protein content (range, 11 to $90 \mathrm{mg}$. per $100 \mathrm{ml}$.), sufficient fluid was available for the estimation of nondialyzable NA as well as for total NA concen-

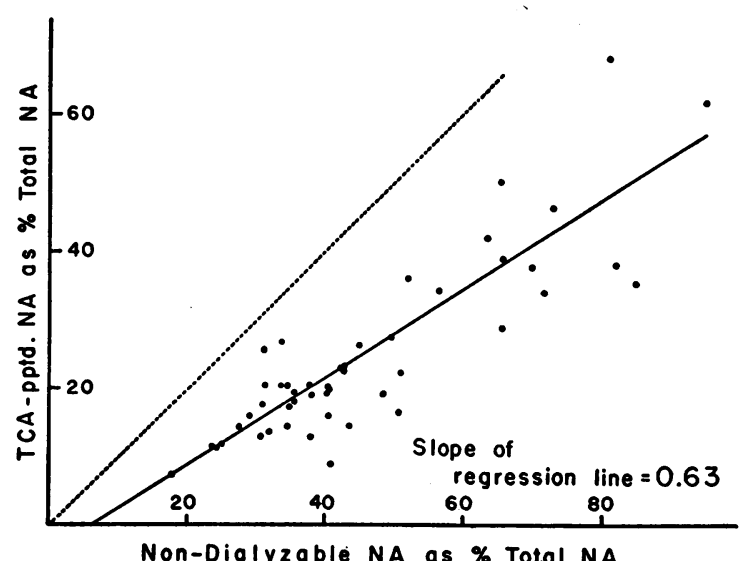

Fig. 8. Relation of Nondialyzable NA Fraction to TCA-PRECIPITATEd Fraction

Showing that the nondialyzable NA fraction of CSF is not equal to the TCA-precipitated fraction, the latter always being less. Dotted lines represent the line along which the points would have fallen, had the two fractions been equivalent to each other. 
tration. The average nondialyzable NA represented 2.0 per cent of the total protein (mean, 2.05 per cent \pm 0.14 ; standard deviation, 0.922 per cent) in these samples with a range of 0.76 to 4.42 per cent. On the other hand the TCApptd. NA represented on the average 0.97 per cent of the total protein (mean, 0.966 per cent \pm 0.0394 ; standard deviation, 0.332 per cent) in the CSF from 71 patients with a range of 0.42 to 2.0 per cent, while the total protein concentration ranged from 11 to $275 \mathrm{mg}$. per cent. In neither case was there any relationship between the protein concentration and the magnitude of the value of bound NA as per cent total protein. In other words, changes in the ratio of protein-bound NA to total protein in the CSF could not be shown to be dependent on changes in protein concentration.

\section{DISCUSSION}

The assessment of the significance of change in concentration of any substance in the CSF requires $(a)$ that the changes observed in any pathological process be appreciably beyond the margins imposed by any concentration gradient for that particular substance, and $(b)$ that all possible changes in the circulation pattern be accounted for before any changes in concentration are related to the pathological process itself. Data presented in this paper clearly show the existence of a concentration gradient for total NA as well as for the dialyzable NA and the protein-bound NA moieties. There appears to exist an inverse relationship between the concentration gradients of protein-bound NA and dialyzable NA. The latter is highest in the ventricle and decreases sharply in the spinal subarachnoid fluid, while the proteinbound NA is in lowest concentration in the ventricle and increases pari passu with the protein concentration as the spinal subarachnoid space is reached. In line with these considerations, changes in the total NA content of CSF occurring with disease processes fall into two categories. The first represents those processes that produce an increase in the total protein concentration of the CSF (irrespective of etiology) and thus produce a rise in the protein-bound NA. In these states the increased NA content is of no greater significance than the nonspecific increase of CSF proteins. This conclusion supports the observa-

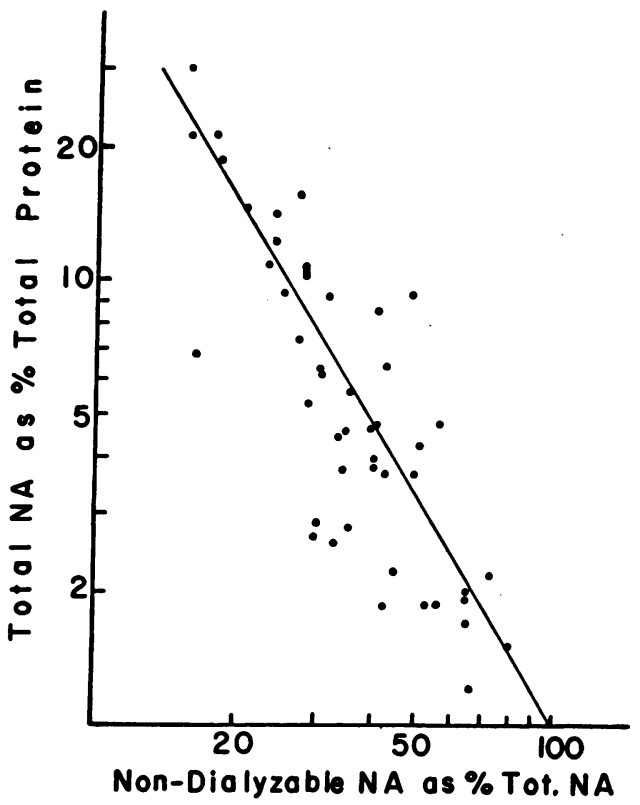

Fig. 9. Relationship of Nondialyzable NA Concentration to CSF total Protein Concentration

The straight line represents the theoretical curve if all the nondialyzable NA of CSF were derived from serum. Thus, if the nondialyzable NA represented all the NA in CSF (100 per cent) then the NA would be 1 per cent of the CSF total protein (the same as in serum).

tions of Ross and Böhm (17). In their limited study of 20 cases, these authors reported that protein-bound NA (measured as TCA-pptd. NA) represented 0.75 to 1.86 per cent of the total protein, with two "normal" values reported as 0.91 and 0.80 per cent of the total protein. The difference found between these TCA-pptd. NA values and those obtained when the nondialyzable NA was analyzed (Figure 8) indicates that, unlike serum, only a portion of the protein-bound NA in CSF is precipitated by TCA. Thus our observations on the nondialyzable NA fraction of CSF obtained from the lumbar subarachnoid space indicate a higher percentage of NA in the proteinbound form (average 2.0 per cent of the total protein, range 0.75 to 4.42 per cent) than in the TCA precipitations by us and by others $(16,17)$. The reason for this difference probably resides in the fact that the CSF contains about 15 times more proteins not precipitated by TCA than does serum, as was recently shown in a detailed study by Bauer (22). The same author showed that those fractions which are not precipitated by TCA be- 
long mostly to the mucoproteins of the $\alpha_{1}$ - and $\alpha_{2}$ globulin class. Since our own studies (11) as well as those of others $(12,13,23)$, have indicated that these $\alpha$ globulins are particularly rich in NA content, the present finding of much higher NA content in the total nondialyzable proteins of CSF as compared with those precipitated by TCA appears to confirm Bauer's results. The proteinbound NA concentration in ventricular fluid does not seem to differ, with respect to the percentage of protein-bound NA to the total protein, from the ranges observed in spinal fluid as long as the pathological process is mainly restricted to the circulation or resorption of CSF, as was evident in cases of hydrocephalus (Table III). On the other hand, ventricular fluid from patients with cerebral edema with varying degrees of cerebral destruction (Table IV, Group A) exhibited a much lower proportion of NA in the proteinbound fraction. We are inclined to believe that the probable explanation for this is that the increase in ventricular protein in these cases was mainly due to exudation of albumin which is known to be essentially free of neuraminic acid $(11,23)$.

In contrast to the changes in the total NA content induced by changes in the protein-bound NA, changes in the dialyzable NA moiety appear to be brought about mainly by changes in the circulation pattern of the CSF. The highest values were found in the ventricles where the outflow from the fourth ventricle was totally obstructed by the phenomenon of Arnold-Chiari (Table III) while lesser concentrations of dialyzable NA prevailed when the hydrocephalus was a communicating one. Similarly, drastic decreases of the dialyzable NA concentration were observed in spinal subarachnoid fluid if fluid was obtained below the site (or sites) where evidence of spinal subarachnoid block existed (Figure 7). In many instances this decrease was evident without an increase in the total protein. Although our proven cases of spinal subarachnoid block are too few to justify any categorical conclusions, it does appear that such a decrease of dialyzable NA concentration in the spinal subarachnoid space may serve as a more sensitive index of physiologic block of CSF circulation than the well known elevation of total protein.
Decreases in the concentration of dialyzable NA were also observed in ventricular fluid (Table IV, Group A). The pathological findings were different in every case at surgery or autopsy. The only common denominator in this admittedly small number of cases was coma with evidence of cerebral edema and increased intracranial pressure. The only explanation that suggests itself is that cerebral edema, with its consequent metabolic disturbances and restrictions in extracellular fluid circulation in the cerebral substance, interferes with the production of dialyzable NA into the ventricular cavity. This finding, taken in conjunction with the fact that in every other instance, irrespective of pathology, the dialyzable NA fraction was found in highest concentration within the ventricular cavity, lends further support to our original suggestion (14) ascribing the presence of this fraction to the metabolic activities of the cerebral substance itself.

Our failure to note any differences between the dialyzable NA fraction of CSF in patients with chronic degenerative disease of the nervous system (Wilson's disease, Huntington's chorea, Alzheimer's disease, Jakob-Creutzfeldt disease, primary cerebellar degeneration and so forth) and that of patients without neurological disease does not appear surprising. It seems unlikely that the NA contributed to the ventricular fluid by a chronic degenerative-destructive process could have any significant reflection in the dialyzable NA moiety of the CSF as a whole because of the steep concentration gradients prevailing for this fraction. This last factor would tend to overshadow any small concentration change in the ventricles.

The results obtained on sequential sampling of CSF at the lumbar subarachnoid space (Figure 4) demonstrate a regularity in the normal concentration gradient of the total NA of CSF. Disturbances in this concentration gradient (Figure 5) and the results of sampling of unequal volumes (Table I) clearly validate the extrapolation of the straight line relationship observed under ideal conditions (Figure 4). The intercept of this straight line with the total NA as per cent total protein abscissa represents the theoretical total NA content of the ventricular fluid, if the total protein is approximately $10 \mathrm{mg}$. per cent. In any 
given case the sequential sampling of equal volumes of CSF from the lumbar spinal subarachnoid space and treatment of the data, as illustrated in Figure 4, should prove a very useful way of estimating the approximate total NA concentration in the ventricle. This is especialy evident in the study of cases in which ventricular fluid is not available, and the method consequently deserves further exploration.

\section{SUMMARY}

Previous observations on the variations of neuraminic acid concentration of cerebrospinal fluid (CSF) have been extended to 262 cases. From this group, several smaller groups of cases in which the diagnosis was established at surgery or autopsy were chosen to correlate the pathophysiological variations of neuraminic acid (NA) content with specific types of pathological processes in the nervous system.

It was shown that the total NA content of CSF represents the sum of two fractions. One of these is the protein-bound NA fraction which increases in nonspecific manner with increasing CSF protein concentration irrespective of the pathological conditions giving rise to this increase. It is in lowest concentration in ventricular fluid, and increases pari passu with the protein concentration in the lumbar subarachnoid fluid. The variations encountered in the relationship of the concentration of this fraction to the total protein concentration appear to reflect the changing proportions of $\alpha_{1}$ - and $\alpha_{2}$-globulin glycoprotein components of the CSF total protein. Unlike its counterpart in the serum the fraction of protein-bound NA precipitated with trichloracetic acid represents only 40 to 60 per cent of the total nondialyzable NA in CSF. The other is the dialyzable NA fraction which is found in highest concentration in the ventricular fluid and decreases exponentially as the lumbar subarachnoid space is reached. This fraction was found to be significantly diminished in ventricular fluid in cases with severe cerebral edema irrespective of etiology. It was also found to be markedly decreased in spinal subarachnoid fluid removed below the site of subarachnoid block, whether the block was at the level of the aqueduct, fourth ventricle or cervical cord. The highest levels were observed in ventricular fluid in cases of noncommunicating hydrocephalus due to obstruction at the level of the fourth ventricle. $\mathrm{Pa}$ tients with chronic degenerative disease exhibited no significant differences in the CSF content of either fraction when compared with patients having no neurological disease.

\section{ACNOWLEDGMENTS}

The authors are indebted to Marilynn K. Rumley, B.S., for valuable assistance through all phases of this study. Our special thanks go to Drs. K. Yada, O. Reinmuth, E. Lewin and A. Waltz, and to all members of the House Staff of the Neurological Unit for their enthusiastic cooperation.

\section{REFERENCES}

1. Klenk, E. The pathological chemistry of the developing brain in Biochemistry of the Developing Nervous System, H. Waelsch, Ed. New York, Academic Press, 1955, pp. 397-410.

2. Heimer, R., and Meyer, K. Studies on sialic acid of submaxillary mucoid. Proc. nat. Acad. Sci. (Wash.) 1956, 42, 728.

3. Zilliken, F. Sialic acid and related compounds in Trans. 2nd Conf. Polysaccharides in Biology. New York, Josiah Macy Jr. Foundation, 1957, pp. 9-40.

4. Klenk, E., Faillard, H., and Lempfrid, H. Ueber die enzymatische Wirkung von Influenzavirus. HoppeSeylers Z. physiol. Chem. 1955, 301, 235.

5. Böhm, P., Dauber, S., and Baumeister, L. Ueber Neuraminsäure, Ihr Vorkommen und Ihre Bestimmung im Serum. Klin. Wschr. 1954, 32, 289.

6. Böhm, P., and Baumeister, L. Ueber das Vorkommen neuraminsäurehaltiger Glycoproteide in Körperflüssigkeiten. Hoppe-Seylers Z. physiol. Chem. 1956, 305, 42.

7. Klenk, E., and Lauenstein, K. Ueber die Glykolipoide und Sphingomyeline des Stromas der Pferdeerythrocyten. Hoppe-Seylers Z. physiol. Chem. 1953, 295, 164.

8. Yamakawa, T., Suzuki, S., and Hattori, T. The chemistry of the lipids of posthemolytic residue or stroma of erythrocytes. V. Glycolipids of erythrocytes stroma and ganglioside. J. Biochem. (Tokyo) 1953, 40, 611.

9. Barry, G. T. Isolation of $\mathrm{N}$-acetylneuraminic acid from colominic acid. Science 1957, 126, 1230.

10. Böhm, P., and Baumeister, L. Ueber die Isolierung der Methoxyneuraminsäure als Spaltprodukt des Serumeiweisses. Hoppe-Seylers Z. physiol. Chem. 1955, 300, 153.

11. Uzman, L. L., and Rosen, H. Partition of neuraminic acid among human serum proteins. Science 1954, $120,1031$. 
12. Baudouin, A., Lewin, J., and Hillion, P. L'acide neuraminique du sérum humain. Sa localisation dans les différentes fractions protéiniques. C. R. Soc. Biol. (Paris) 1956, 150, 1316.

13. Jayle, M.-F.. Biochimie et intérêt clinique des $\alpha_{1}$ et $\alpha_{2}$-séromucoïdes. Schweiz. med. Wschr. 1956, 86, 1425.

14. Uzman, L. L., and Rumley, M. K. Neuraminic acid as a constituent of human cerebrospinal fluid. Proc. Soc. exp. Biol. (N. Y.) 1956, 93, 497.

15. Südhof, H., Kellner, H., Schönenberger, M., Haupt, H., and Clauditz, C. Zum Eiweisszucker normaler und pathologischer Seren. Hoppe-Seylers Z. physiol. Chem. 1957, 309, 136.

16. Roboz, E., Murphy, J. B., Hess, W. C., and Forster, F. M. Isolation and determination of the glycoproteins in cerebrospinal fluid. Proc. Soc. exp. Biol. (N. Y.) 1955, 89, 691.

17. Ross, J., and Böhm, P. Neuraminsäurehaltige Glyko- proteide des Liquor Cerebrospinalis bei Erkrankungen des Nervensystems. Klin. Wschr. 1957, $35,351$.

18. Werner, I., and Odin, L. On the presence of sialic acid in certain glycoproteins and in gangliosides. Acta Soc. med. upsalien. 1952, 57, 230.

19. Klenk, E., Faillard, H., and Lempfrid, H. Ueber die Natur des Zellrezeptors von Influenzavirus. Photographie u. Wissenschaft 1956, 5, 3.

20. Newburgh, R. W., and Cheldelin, V. H. Oxidation of carbohydrates by the pea aphid, Macrosiphum pisi (KLTB). J. biol. Chem. 1955, 214, 37.

21. Robins, E. Personal communication.

22. Bauer, H. Zur Frage der Identität der Liquorproteine mit den Eiweisskörpern des Blutserums. III. Die Mucoproteine des Liquors. Dtsch. Z. Nervenheilk. 1957, 176, 126.

23. Dźulynska, J. Sialic acid in serum-protein fractions. Bull. Acad. pol. Sci. Cl. 2 1956, 4, 257. 